\title{
Variation of Selected Physicochemical and Hydrological Properties of Soils in Different Tropical Land Use Systems of Nepal
}

\author{
Sujita Shrestha and Gandhiv Kafle ii \\ Faculty of Forestry, Agriculture and Forestry University, Hetauda, Nepal \\ Correspondence should be addressed to Gandhiv Kafle; gandhivkafle@gmail.com
}

Received 11 June 2020; Revised 28 August 2020; Accepted 1 September 2020; Published 14 September 2020

Academic Editor: Evgeny Abakumov

Copyright (c) 2020 Sujita Shrestha and Gandhiv Kafle. This is an open access article distributed under the Creative Commons Attribution License, which permits unrestricted use, distribution, and reproduction in any medium, provided the original work is properly cited.

\begin{abstract}
Different land use systems can have different soil properties. It is important to study the soil properties for wise use and sustainable management of land resources. This article reports the findings of a research conducted in Makwanpur district of Nepal, to determine and compare the selected physicochemical and hydrological properties of soil in forest, rainfed agriculture land, and grassland. These forest, agriculture land, and grassland represent tropical land use systems. Soil samples were collected from 0 to $30 \mathrm{~cm}$ depths of soil profile from nine randomly distributed pits dug in forest, grassland, and rainfed agriculture land in 2019. Soil samples were analyzed in the laboratory to determine the soil properties using standard methods. Bulk density, porosity, moisture content and infiltration, $\mathrm{pH}$, total nitrogen, available potassium, and available phosphorus were quantified from the soils samples. It was found that the highest BD was found in the grassland $\left(1.29 \mathrm{~g} / \mathrm{cm}^{3}\right)$ followed by the forest $\left(1.23 \mathrm{~g} / \mathrm{cm}^{3}\right)$ and rainfed agriculture land $\left(1.18 \mathrm{~g} / \mathrm{cm}^{3}\right)$. The highest porosity was found in rainfed agriculture land $(55.50 \%)$ followed by the forest $(53.74 \%)$ and grassland (51.63\%). The highest MC was found in the grassland (26.94\%) followed by the forest (10.17\%) and rainfed agriculture land $(9.92 \%)$. The mean cumulative infiltration amount was highest in the rainfed agriculture land $(39.27 \mathrm{~cm})$ followed by the forest $(33.47 \mathrm{~cm})$ and grassland $(8.4 \mathrm{~cm})$. The highest soil $\mathrm{pH}$ was found in the grassland $(7.91)$ and the lowest $\mathrm{pH}(5.70)$ in the forest. The highest level of total nitrogen was found in rainfed agriculture land $(0.121 \%)$, followed by the forest $(0.106 \%)$ and grassland $(0.096 \%)$. The highest level of available phosphorous was found in rainfed agriculture land ( 84.94 ppm), followed by the forest $(67.76 \mathrm{ppm})$ and grassland (6.69). The highest level of available potassium was found in rainfed agriculture land $(154.24 \mathrm{ppm})$, followed by the forest $(84.49 \mathrm{ppm})$ and the grassland $(44.71 \mathrm{ppm})$. Bulk density, porosity, and total nitrogen were not found to be significantly different and other soil properties were found to be significantly different between different land use systems. The contribution of farmers in maintaining soil properties on the farmlands is clearly reflected in the results, so their knowledge on soil management needs to be explored and adapted for wise use and sustainable management of other land use systems.
\end{abstract}

\section{Introduction}

Soil is the substrate of all living organisms in the terrestrial ecosystems, which contains nutrient reserves and supports many biological processes in vegetation development. Forest biodiversity directly depends on abiotic factors like forest soil and microclimate variables, which have vital roles to sustain forest biodiversity [1]. Land use involves the management and modification of natural environment or wilderness into built environment such as settlement and seminatural habitats such as arable fields, pastures, and managed woods.

Different land use systems exist in the world with variation in soil physical, chemical, and biological properties of soil. Soil properties vary due to different land use and management practices [2]. Soil properties also differ according to the land management practices, so even the similar land use system can have different soil properties. Land use and soil management practices influence the soil nutrients and related soil processes [3]. As a result, they can 


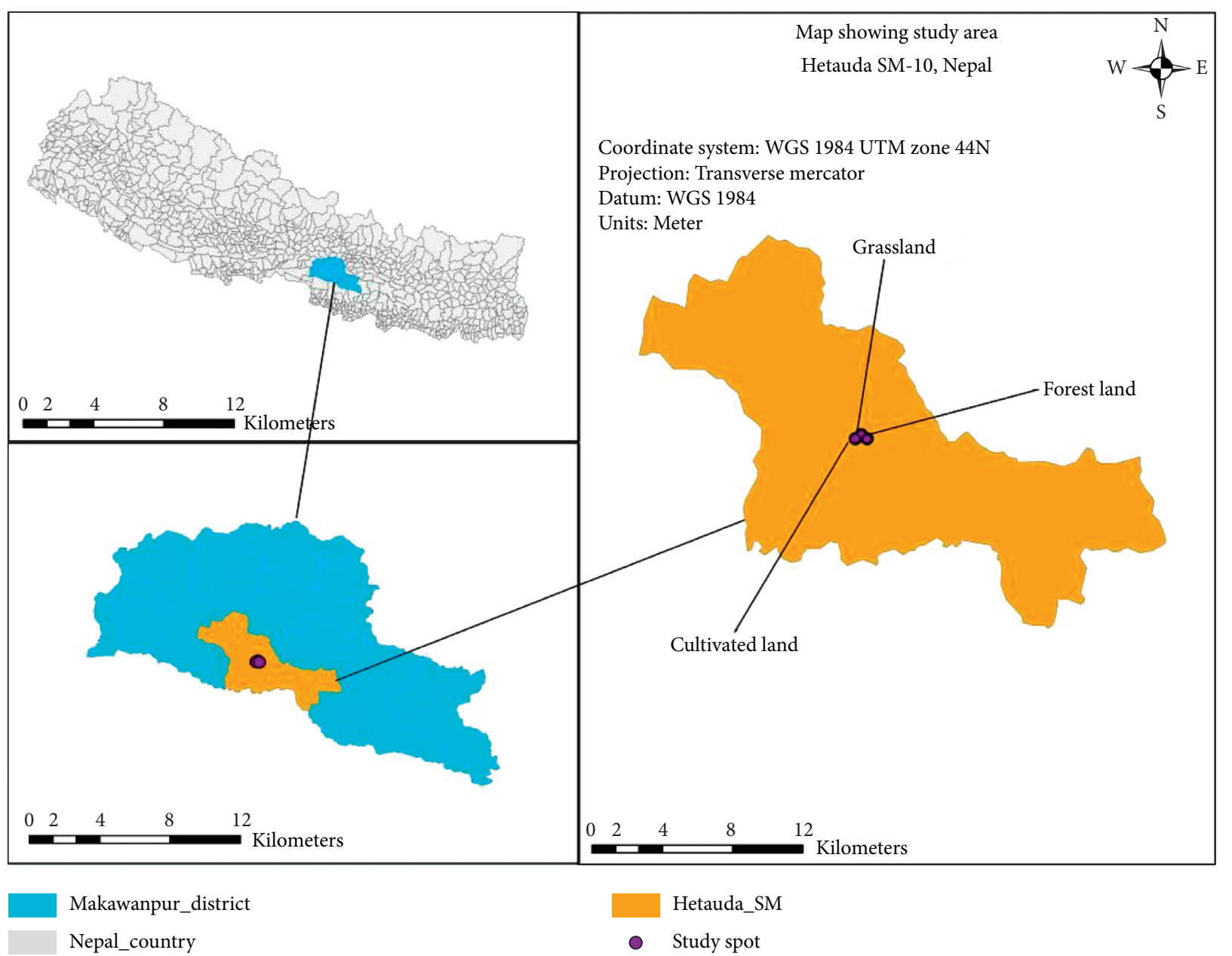

Figure 1: Map showing research sites.

modify the processes of transport and redistribution of nutrients in the soils [4].

Land degradation resulting from land use change has been a major global challenge since the $20^{\text {th }}$ century and will be focused as a major topic on the international agenda in the $21^{\text {st }}$ century [5]. National Land Use Policy of Nepal has categorized lands of Nepal into seven classes: forestry, grassland, agricultural land, residential, commercial, archeological, and water bodies [6]. Rapid change in land use and land cover in Nepal has been felt due to the high population growth. Nepal is facing a severe problem of soil quality deterioration and of subsequent low crop yields because of different human activities and land use changes which cause lowering of organic matter, nutrients, and their hydrological parameters [7]. Dry soft rocks are the major sources of soils in this area. Variegated mudstone, siltstone, and shale with smaller amounts of fine-grained sandstone are found in this area [8]. The area is characterized by ancient river terraces, depositional basin, and moderately sloping terrain [9].

The evaluation of soil properties under the different land use systems is important to understand the role of different land uses and their effects on soil differentiation [10]. Soil management systems and changes in land use strongly influence soil physical and chemical properties [11]. The variation of soil properties should be monitored and quantified to understand the effects of land use and management systems on soils [12] so that this knowledge can be used in soil management. Though knowledge on variation of soil properties is essential in devising proper land use planning, previous researches devoted to this topic are absent in Hetauda Submetropolitan area. The lack of such researches could be due to low priority of the developing nations in allocating research funds across wider geographic areas over time. In this context, this study was carried out in topical land use systems to determine and compare the selected soil chemical and hydrological properties in forest soil, agriculture soil, and grassland soil in tropical region of Nepal.

\section{Materials and Methods}

2.1. Research Sites. The research was conducted in three land use systems: forest, grassland, and rainfed agriculture in Makawanpur district, a tropical region of Nepal $\left(27^{\circ} 25^{\prime} \mathrm{N}\right.$ latitude and $85^{\circ} 02^{\prime} \mathrm{E}$ longitude; 300-390 $\mathrm{m}$ above the sea level) in 2019. The soils of the Makawanpur district are Fluvisols, Cambisols, and Regosols $[9,13]$. 
A tropical forest in ward number 10 of Hetauda SubMetropolitan with total area 94 hectares was selected for data collection (Figure 1).

The forest represented a mature tropical forest with Shorea robusta as dominant species. The associated species in the forest are Dalbergia sissoo, Acacia catechu, Trewia nudiflora, Bombax ceiba, etc. (own observation). According to Rautiainen [14], the estimated age of the stand with average diameter above $48 \mathrm{~cm}$ is 120 years. Hence, the study assumed the age of the stand at around 120 years observing the maturity level of the dominant Shorea robusta (own observation), though scientific assessment of stand age, is yet to be conducted.

A tropical grassland adjacent to the forest was selected for data collection, with a total area of around 3 hectares (Figure 1).

Small grasses like Cynodon dactylon, Artemisia vulgaris, and Imperata cylindrica (own observation). were major species on the grassland, with usual cattle grazing.

Rainfed agricultural land nearby the forest and grassland was selected for data collection, with a total area around 4 hectares (Figure 1).

2.2. Soil Sampling. A stratified random sampling design was used for collecting soil samples in the three representatives land use systems purposively selected: Forest, grassland and rainfed agriculture land. Soil samples, each around half kilogram, were collected from 0 to $30 \mathrm{~cm}$ depths of soil profile from nine randomly distributed pits dug in forest, grassland, and rainfed agriculture land. One additional soil sample (undisturbed soil sample) from each pit was collected using the soil core sampler to determine the bulk density, porosity, and moisture content of the soil.

Soil formation is predominantly a vertical process related to climate, parent material, relief, organisms, time, and spatial position [15]. The inputs from weathering and humus are strongest at the soil surface and decrease with depth [16]. The organic matter in soil tends to concentrate in the upper horizons of the soil because of high input from the vegetation on soil surface. According to IPCC [17], roughly half of the soil organic carbon of the top $100 \mathrm{~cm}$ of mineral soil is held in the upper $30 \mathrm{~cm}$ layer. It is good practice to include a minimum depth of at least $30 \mathrm{~cm}$ in nutrient stock assessment. The carbon held in the upper profile is often the most chemically decomposable and the most directly exposed to natural and anthropogenic disturbances. So, we focused our soil sampling upto $30 \mathrm{~cm}$ soil depth.

The collected soil samples were packed, labelled, airdried, and taken to the Soil Test Laboratory of a NonGovernmental Organization (NGO)-Local Initiatives for Biodiversity, Research and Development (LIBIRD), Kaski, for analysis. The overall field measurement methods were based on guidelines of Asia Network for Sustainable Agriculture and Bio resource ANSAB [18].

2.3. Infiltration Test. The infiltration test was carried out in the forest, grassland, and rainfed agriculture land using double ringed infiltrometer [19].
2.4. Soil Analysis. The percentage of moisture content (MC) in the soil was obtained by

$$
\mathrm{MC}=\left(\frac{\left(M_{1}-M_{2}\right)}{M_{2}}\right) * 100,
$$

where $M_{1}=$ fresh weight of soil.

$$
M_{2}=\text { oven dry weight of soil. }
$$

Bulk density (BD) of the soil was determined using the soil core sampler of volume $245.22 \mathrm{~cm}^{3}(\mathrm{~V})$ [20].

Porosity $(P)$ of the soil was determined using the equation taking where the particle density (PD) equals $2.66 \mathrm{~g} / \mathrm{cm}^{3}$ :

$$
P=\left(1-\left(\frac{\mathrm{BD}}{\mathrm{PD}}\right)\right) * 100 \%
$$

The infiltration rate (IR) was obtained by

$$
\text { IR }=\frac{\text { (initial water level }- \text { final water level) }}{t},
$$

where $t$ is the time taken to drop the water from initial level to the final level in the inner ring in minutes. Cumulative infiltration was obtained by adding each infiltration amount in each time recorded.

Soil $\mathrm{pH}$ was determined using the distilled water method as indicated by Davis and Freitas [21].

Nitrogen was determined by using the semi-Kjeldhal Dri-Block method [22].

Available phosphorus was determined by using the Bray-p1 method [23].

Potassium in soil was determined by the flame photometer with $1 \mathrm{M}$ ammonium acetate extracting solution [24].

2.5. Statistical Analysis. Statistical Package for Social Science (SPSS) software (IBM SPSS Statistics, IBM Corporation, Version 20) was used for statistical analysis of the data. Analysis of variance (ANOVA) and least significance difference (LSD) tests were conducted to test the significance difference of the variables.

\section{Results and Discussion}

\subsection{Comparison of Physical Properties on Land Use Systems}

3.1.1. Bulk Density $(B D)$. The highest $\mathrm{BD}$ was found in the grassland $\left(1.29 \mathrm{~g} / \mathrm{cm}^{3}\right)$ followed by the forest $\left(1.23 \mathrm{~g} / \mathrm{cm}^{3}\right)$ and rainfed agriculture land $\left(1.18 \mathrm{~g} / \mathrm{cm}^{3}\right)$, similar to the results of Muche et al. [25], who reported that the highest average value of $\mathrm{BD}\left(1.2 \mathrm{gm} / \mathrm{cm}^{3}\right)$ was obtained under the grazing land. The ANOVA test shows that there was no significant difference of $\mathrm{BD}(p=0.637)$ between different land use systems at $5 \%$ level of significance (Table 1). The lowest $\mathrm{BD}$ of the rainfed agriculture land might be due to the loosening of soil due to frequent nonmechanized tillage operations. The highest $\mathrm{BD}$ of the grassland might be due to the regular grazing and movement of the humans on the ground which causes soil compaction [26]. Well-aggregated 
TABLE 1: Effect of land use system on soil properties.

\begin{tabular}{|c|c|c|c|c|c|c|c|c|}
\hline & $\mathrm{BD}\left(\mathrm{g} / \mathrm{cm}^{3}\right)$ & SP (\%) & MC (\%) & $\mathrm{CI}(\mathrm{cm} / \mathrm{min})$ & $\mathrm{pH}$ & $\mathrm{N}(\%)$ & $\mathrm{P}(\mathrm{ppm})$ & $\mathrm{K}(\mathrm{ppm})$ \\
\hline Forest & $1.23 \pm 0.15$ & $53.74 \pm 5.643$ & $10.17 \pm 0.523$ & $33.47 \pm 12.878$ & $5.70 \pm 0.146$ & $0.106 \pm 0.032$ & $67.76 \pm 11.899$ & $84.49 \pm 10.78$ \\
\hline Grassland & $1.29 \pm 0.069$ & $51.63 \pm 2.602$ & $26.94 \pm 2.387$ & $8.4 \pm 1.044$ & $7.91 \pm 0.021$ & $0.096 \pm 0.019$ & $6.69 \pm 2.324$ & $44.71 \pm 6.512$ \\
\hline $\begin{array}{l}\text { Rainfed } \\
\text { agriculture land }\end{array}$ & $1.18 \pm 0.147$ & $55.50 \pm 5.52$ & $9.92 \pm 1.673$ & $39.27 \pm 18.831$ & $6.55 \pm 0.260$ & $0.121 \pm 0.009$ & $84.94 \pm 6.338$ & $154.24 \pm 60.294$ \\
\hline$P<0.05$ & 0.637 & 0.636 & 0.000 & & 0.000 & 0.434 & 0.000 & 0.025 \\
\hline$P<0.05$ & & & & 0.060 & & & & \\
\hline
\end{tabular}

Note. BD: bulk density of the soil. SP: porosity, MC: moisture content, CI: cumulative infiltration of the soil, pH: pH value of the soil, N: total nitrogen, P: available phosphorus, and K: available potassium in the soil.

loose and porous soil has high organic matter and lower bulk density while poorly aggregated soil has low organic matter content and high bulk density that make total pore spaces become greater [27].

3.1.2. Soil Porosity (SP). The highest porosity was found in rainfed agriculture land (55.50\%) followed by the forest (53.74\%) and grassland (51.63\%). The ANOVA test shows that there was no significant difference of porosity ( $p=0.636$ ) between different land use systems at $5 \%$ level of significance (Table 1). Porosity was highest in the rainfed agriculture land which may be due to the frequent addition of manure and nonmechanized tillage. The bulk density might have played a role in the percentage of the porosity which has reported that the decrease in bulk density with organic amendments and nutrients is directly related to the increased porosity, which is related to the improved soil aggregation [28]. Cattle grazing and human movement might have caused substantial reduction of the soil pore space causing lowest porosity in the grassland [26].

3.1.3. Moisture Content (MC). The highest $\mathrm{MC}$ was found in the grassland (26.94\%) followed by the forest $(10.17 \%)$ and rainfed agriculture land (9.92\%). The ANOVA test shows that there was significant difference of MC $(p \leq 0.001)$ between different land use systems at $5 \%$ level of significance (Table 1). The LSD test shows that there was significant difference of MC between grassland and forest and between grassland and rainfed agriculture land but no significant difference between forest and rainfed agriculture land at 5\% level of significance (Table 2). A similar result was found by Tuffour et al. [26] in which the moisture content of the soil was lower in the ungrazed field (17\%) in relation to the grazed field $(24 \%)$. It was stated that this result could be due to lower porosity resulting from the higher bulk density in the grazed field. Reduction of the pores in the grassland may have caused a restriction in the transmission of water with the soil becoming frequently too wet [29] resulting in an increased amount of water available on the soil surface.

3.1.4. Infiltration Parameter. The mean cumulative infiltration amount was highest in the rainfed agriculture land $(39.27 \mathrm{~cm})$ followed by the forest $(33.47 \mathrm{~cm})$ and grassland $(8.4 \mathrm{~cm})$ (Table 1).
For the first minute, the mean infiltration rate of the rainfed agriculture land, forest, and grassland was $1.9 \mathrm{~cm} / \mathrm{min}$, $1.53 \mathrm{~cm} / \mathrm{min}$, and $0.567 \mathrm{~cm} / \mathrm{min}$, respectively.

The ANOVA test shows that there was significant difference of cumulative infiltration amount $(p=0.060)$ between different land use systems at $10 \%$ level of significance (Table 1). The LSD test at 10\% level of significance revealed that there is significance difference in cumulative infiltration amount in between grassland and rainfed agriculture land $(p=0.029)$ and forest and grassland but no significant difference between forest and rainfed agriculture land (Table 2).

Higher infiltration was found in the rainfed agriculture land which might be due to the higher porosity (55.40\%). The lower porosity (51.63\%) in the grassland caused decrease in infiltration due to few pores and the compaction of soil. Also, the moisture content of the land might also be the reason for the difference in the infiltration amount. Similar study was done by the Tuffour et al. [26], and they found a lower infiltration amount in the grazed compacted field with respect to the ungrazed field where the terminal infiltration amount of spot 1 on the ungrazed field was $1320 \mathrm{~mm}$ compared to $510 \mathrm{~mm}$ of the grazed field.

\subsection{Comparison of Chemical Properties on Land Use Systems}

3.2.1. Soil $p H$. The highest soil $\mathrm{pH}$ was found in the grassland (7.91) and the lowest $\mathrm{pH}$ (5.70) in the forest. The ANOVA test shows that there was significant difference of soil $\mathrm{pH}(p \leq 0.001)$ between different land use systems at $5 \%$ level of significance (Table 1). The LSD comparison at $5 \%$ level of significance between different land use systems for the soil $\mathrm{pH}$ revealed that there is a significance difference between all land use systems (Table 2).

The lowest $\mathrm{pH}$ value of the forest soil reveals that the forest soil is acidic which might be due to the presence of the dominant Shorea robusta tree in the forest [30]. The highest $\mathrm{pH}$ value of the grassland reveals that the grassland soil is basic which might be due to the accumulation of the salt concentration because of the nearer distance from the river. The $\mathrm{pH}$ value of the rainfed agriculture land is around neutral (6.55) which might be due to the ongoing soil management practices, for example, use of compost and proper irrigation. Similar results were found by the Islam and Weil [31], where forests and reforested soils contributed significantly to lower $\mathrm{pH}$ values than cultivated and grassland soils in Bangladesh. 
TABLE 2: LSD comparison between land use systems on soil properties.

\begin{tabular}{|c|c|c|c|c|c|c|}
\hline Land use & Land use & $\mathrm{pH}$ & $\mathrm{P}(\mathrm{ppm})$ & $\mathrm{K}(\mathrm{ppm})$ & MC (\%) & $\mathrm{CI}(\mathrm{cm} / \mathrm{min})$ \\
\hline \multirow{2}{*}{ Forest } & Grassland & 0.000 & 0.000 & 0.220 & 0.000 & 0.059 \\
\hline & Rainfed agriculture land & 0.001 & 0.037 & 0.053 & 0.862 & 0.609 \\
\hline \multirow{2}{*}{ Grassland } & Forest & 0.000 & 0.000 & 0.220 & 0.000 & 0.059 \\
\hline & Rainfed agriculture land & 0.000 & 0.000 & 0.009 & 0.000 & 0.029 \\
\hline \multirow{2}{*}{ Rainfed agriculture land } & Forest & 0.001 & 0.037 & 0.053 & 0.862 & 0.609 \\
\hline & Grassland & 0.000 & 0.000 & 0.009 & 0.000 & 0.029 \\
\hline
\end{tabular}

Note. $\mathrm{pH}$ : pH value of the soil, N: total nitrogen, P: available phosphorus, K: available potassium in the soil, MC: moisture content, CI: cumulative infiltration of the soil.

3.2.2. Total Nitrogen. The highest level of total nitrogen was found in rainfed agriculture land $(0.121 \%)$, followed by the forest $(0.106 \%)$ and grassland $(0.096 \%)$. The ANOVA test shows that there was no significant difference of total nitrogen ( $p=0.434$ ) between different land use systems at $5 \%$ level of significance (Table 1). The highest level of total nitrogen in rainfed agriculture land might be due to the cultivation of the leguminous crops, mulching of such crops, and the application of the compost as well as inorganic fertilizers. The lowest level of total nitrogen in the grassland might be due to the sparse vegetation due to human and livestock disturbance.

3.2.3. Available Phosphorous. The highest level of available phosphorous was found in rainfed agriculture land (84.94 ppm), followed by the forest $(67.76 \mathrm{ppm})$ and grassland (6.69). The ANOVA test shows that there was significant difference of available phosphorus $(p \leq 0.001)$ between different land use systems at $5 \%$ level of significance (Table 1). The LSD comparison at 5\% level of significance between different land use systems for the available phosphorus revealed that there is significant difference between all land use systems (Table 2). Highest amount of available phosphorous in the rainfed agriculture land might be due to the ongoing soil management practices, for example, application of manure and fertilizers. The lowest available phosphorus content in the forest soil might be due to forest vegetation with availability of different plant species which absorbs a larger amount of available phosphorus causing to deplete it in the soil [32]. Leaching might be the cause for lowest level of available phosphorus in the soil of the grassland. Kharal et al. [33] found a similar result where available phosphorus was the highest in the vegetable farm $\left(41.07 \mathrm{mg} \mathrm{kg}^{-1}\right)$ and was the lowest in grazing land $\left(2.89 \mathrm{mg} \mathrm{kg}^{-1}\right)$. Bizuhoraho et al. [34] and Ivezic et al. [35] also found the higher available phosphorus in cultivated land than in the forest.

3.2.4. Available Potassium (ppm). The highest level of available potassium was found in rainfed agriculture land (154.24 ppm), followed by the forest $(84.49 \mathrm{ppm})$ and the grassland $(44.71 \mathrm{ppm})$. The ANOVA test shows that there was significant difference of available potassium $(p=0.025)$ between different land use systems at $5 \%$ level of significance (Table 1). The LSD comparison at 5\% level of significance between different land use systems for the available potassium revealed that there is significance difference between grassland and rainfed agriculture land (Table 2). The highest level of available potassium in the rainfed agriculture land might be due to the litter mixing with soil and undergoing recycling to release available potassium and applying ashes of the burned crop residues [36] and application of the cow dung, poultry manure and compost manure in the field. The lowest amount of available potassium in the grassland might be due to leaching of the available potassium from soil surface and low external input [36] and might be due to the disturbance to the soil from trampling by livestock, human movement, and soil compaction. Kharal et al. [33] found similar result where available potassium was the highest in the vegetable farm $\left(130.2 \mathrm{mg} \mathrm{kg}^{-1}\right)$ and lowest in grazing land $\left(36.8 \mathrm{mg} \mathrm{kg}^{-1}\right)$. Ivezic et al. [35] also found the higher available potassium in cultivated land than in the forest.

\section{Conclusion}

This article indicates the first reporting of hydrological properties in soils of tropical forest, rainfed agriculture land, and grassland in Nepal. Results of this research show evidence of variation of soil physicochemical and hydrological properties in different land use systems of tropical region of Nepal. The soils with external disturbances showed low levels of important physiochemical and hydrological properties of the soils. The control of rampant grazing on the grassland will improve the hydrological properties of the grassland such as porosity and infiltration. The rainfed agriculture land shows superiority in soil properties, so existing farming practices should be promoted, and associated indigenous knowledge should be documented and disseminated. How soils have changed over time under specific management scenarios needs to be studied in-depth.

\section{Data Availability}

The data supporting the conclusions of this study are available from the first author upon request.

\section{Conflicts of Interest}

The authors declare that there are no conflicts of interest regarding the publication of this article.

\section{Acknowledgments}

The data collection for this research was supported by the Faculty of Forestry, Agriculture and Forestry University, Nepal. The authors are highly grateful to the Faculty of Forestry, Agriculture and Forestry University, for providing lab equipment and library facility. 


\section{References}

[1] P. K. Pandey, J. D. S. Negi, and S. C. Sharma, "Plant species diversity, composition, gradient analysis and regeneration behaviour of some tree species in a moist temperate western Himalayan forest ecosystem," Indian Forester, vol. 128, no. 8, pp. 869-886, 2002.

[2] D. J. Spurgeon, A. M. Keith, O. Schmidt, D. R. Lammertsma, and J. H. Faber, "Land-use and land-management change: relationships with earthworm and fungi communities and soil structural properties," BMC Ecology, vol. 13, no. 1, p. 46, 2013.

[3] I. Celik, "Land-use effects on organic matter and physical properties of soil in a southern Mediterranean highland of Turkey," Soil and Tillage Research, vol. 83, no. 2, pp. 270-277, 2005.

[4] A. Kiflu and S. Beyene, "Effects of different land use systems on selected soil properties in South Ethiopia," Journal of Soil Science and Environmental Management, vol. 4, no. 5, pp. 100-107, 2013.

[5] H. Eswaran, R. Lal, and P. F. Reich, Land Degradation: An Overview in: Bridges, Taylor \& Francis, Oxford, United Kingdom, 2001.

[6] MoLRM, Land Use Policy 2015, Ministry of Land Reform and Management (MoLRM), Kathmandu, Nepal, 2015.

[7] N. R. Shrestha and D. Conway, "Population pressure and land resources in Nepal: a revisit, twenty years later," The Journal of Developing Areas, vol. 33, no. 2, pp. 245-268, 1999.

[8] B. N. Upreti, "An overview of the stratigraphy and tectonics of the Nepal Himalaya," Journal of Asian Earth Sciences, vol. 17, no. 5-6, pp. 577-606, 1999.

[9] LRMP, Land Utilization Report, Land Resource Mapping Project, Kathmandu, Nepal, 1986.

[10] J. C. Sharma and Y. Sharma, "Effect of forest ecosystems on soil properties-a review," Agricultural Reviews, vol. 25, p. 16, 2004.

[11] N. R. Hulugalle, L. A. Lobry de Bruyn, and P. Entwistle, "Residual effects of tillage and crop rotation on soil properties, soil invertebrate numbers and nutrient uptake in an irrigated Vertisol sown to cotton," Applied Soil Ecology, vol. 7, no. 1, pp. 11-30, 1997.

[12] K. Kilic, S. Kilic, and R. Kocyigit, "Assessment of spatial variability of soil properties in areas under different land use," Bulgarian Journal of Agricultural Science, vol. 18, no. 5, pp. 722-732, 2012.

[13] IUSS Working Group WRB, "World reference base for soil resources 2014, update 2015 International soil classification system for naming soils and creating legends for soil maps," World Soil Resources Reports No. 106, FAO, Rome, Italy, 2015.

[14] O. Rautiainen, Growth Dynamics and Management of Shorea Robusta Forests in Southern Nepal, Faculty of Forestry, University of Joensuu, Joensuu, Finland, 1999.

[15] A. B. McBratney, M. L. Mendonça Santos, and B. Minasny, "On digital soil mapping," Geoderma, vol. 117, no. 1-2, pp. 3-52, 2003.

[16] T. Scholten, P. Goebes, P. Kühn et al., "On the combined effect of soil fertility and topography on tree growth in subtropical forest ecosystems-a study from SE China," Journal of Plant Ecology, vol. 10, no. 1, pp. 111-127, 2017.

[17] Goebes, Good Practice Guidance for Land Use, Land-Use Change and Forestry, p. 590, Intergovernmental Panel on Climate Change, Geneva, Switzerland, 2003.

[18] ANSAB, Forest Carbon Stock Measurement: Guidelines for Measuring Carbon Stocks in Community-Managed Forests, ANSAB, Kathmandu, Nepal, 2010.
[19] A. Klute, Methods of Soil Analysis, Part 1 Physical and Mineralogical Methods, Wiley, Hoboken, NY, USA, 1986.

[20] G. R. Blake and K. H. Harte, "Bulk density," in Methods of Soil Analysis, A. Klute, Ed., American Soceity of Agronomy, Madison, WI, USA, 1986.

[21] J. Davis and F. Freitas, "Physical \& chemical methods of soil \& water analysis," pp. 65-67, FAO of United Nations, Rome, Italy, 1970.

[22] J. M. Bremner, "Determination of nitrogen in soil by the Kjeldahl method," The Journal of Agricultural Science, vol. 55, no. 1, pp. 11-31, 1960.

[23] R. H. Bray and L. T. Kurtz, "Determination of total, organic, and available forms of phosphorus in soils," Soil Science, vol. 59, no. 1, pp. 39-46, 1945.

[24] D. Knudsen, G. A. Peterson, and P. F. Pratt, "Lithium, sodium, and potassium," Methods of Soil Analysis. Part 2. Chemical and Microbiological Properties, pp. 225-246, American Soceity of Agronomy, Madison, WI, USA, 1982.

[25] M. Muche, A. Kokeb, and E. Molla, "Assessing the physicochemical properties of soil under different land use types," Journal of Environmental \& Analytical Toxicology, vol. 5, no. 5, 2015.

[26] H. O. Tuffour, M. Bonsu, and A. A. Khalid, "Assessment of soil degradation due to compaction resulting from cattle grazing using infiltration parameters," International Journal of Scientific Research in Environmental Sciences, vol. 2, no. 4, pp. 139-149, 2014.

[27] United States Department of Agriculture, "Soil quality kit, guide for educators. National resources conservation services," 2017, https://www.nrcs.usda.gov.

[28] G. Gudid and J. E. Hall, "Effects of sewage sludge on the physical and chemical properties of soils," Effects of sewage sludge on the physical and chemical properties of soils," in Processing and Use of Sewae Sludge, P. L'Hermite and H. Ott, Eds., D. Reidel Publishing. Co., Dordrecht, Netherlands, 1984.

[29] D. Relf, "Managing compacted and heavy soils," The Virginia Newsletter, vol. 8, no. 6, 1997.

[30] S. K. Sharma and R. K. Das, "Soil nutrient status in the Sal (Shorea robusta) forests of Goalpara district, Assam," Journal of Advanced Plant Sciences, vol. 4, pp. 14-17, 2009.

[31] K. R. Islam and R. R. Weil, "Land use effects on soil quality in a tropical forest ecosystem of Bangladesh," Agriculture, Ecosystems \& Environment, vol. 79, no. 1, pp. 9-16, 2000.

[32] G. Tilahun, "Soil fertility status as influenced by different land uses in Maybar areas of South Wello Zone, North Ethiopia," M.Sc. thesis, p. 40, Haramaya University, Haramaya, Ethiopia, 2007.

[33] S. Kharal, B. Khanal, and D. Panday, "Assessment of soil fertility under different land-use systems in Dhading district of Nepal," Soil Systems, vol. 2, no. 4, p. 57, 2018.

[34] T. Bizuhoraho, A. Kayiranga, N. Manirakiza, and K. A. Mourad, "The effect of land use systems on soil properties; a case study from Rwanda," Sustainable Agriculture Research, vol. 7, no. 2, pp. 30-40, 2018.

[35] V. Ivezic, Z. Loncaric, K. Karalic, B. Popovic, and B. Ram, Effect of Different Land Use on Main Soil PropertiesFaculty of Agriculture, University of East Sarajevo, Lukavica, East Sarajevo, 2013.

[36] R. P. Chauhan, K. R. Pande, and S. Thakur, "Soil properties affected by land use systems in Western Chitwan, Nepal," International Journal of Applied Sciences and Biotechnology, vol. 2, no. 3, pp. 265-269, 2014. 